\title{
The quadratic relationship between working capital management and firm performance: Evidence from the Nigerian economy
}

\author{
Sunday Simon \\ Universiti Utara Malaysia, Malaysia \\ Norfaiezah Sawandi \\ Universiti Utara Malaysia, Malaysia \\ Mohamad Ali Abdul-Hamid \\ University of Sharjah, U.A.E
}

\section{Keywords}

Working capital management, quadratic, deviation, firm performance, cash conversion cycle, optimal working capital investment level.

\begin{abstract}
Optimal investment in working capital is vital to provide liquidity and enhance firm performance. This paper seeks to determine the quadratic relationship between working capital management (WCM) and firm performance. Also, this paper examines the effect of deviation from optimal WCM on firm performance. Therefore, the study uses a sample of 75 non-financial firms listed on the Nigerian Stock Exchange from 2007 to 2015. It adopts the cash conversion cycle component of working capital management to evaluate the quadratic assumption using panel regression. The empirical results from the sample of the study indicate that the relationship between working capital management and firm performance is quadratic. This study also found that an optimal level exits at which investments in working capital will yield the maximum return. This study concludes that deviation from the optimal level of investments in WCM (either above or below) affects the performance of firms. The study, therefore, recommends that firms should promote best practices for maintaining optimal working capital investment level to enhance their performance and sustain growth.
\end{abstract}

Corresponding author: Sunday Simon

Email address for corresponding author: simonsunday016@gmail.com

First submission received: 10th April 2017

Revised submission received: 23rd May 2017

Accepted: 26 th June 2017

\section{Introduction}

Working Capital Management (WCM) is a strategy for generating free cash flow which greatly facilitates a firm's operations and performances. Over time, the findings of extant studies on the effect of WCM on firm performance have been inconsistent. This inconsistency has been linked to the non-linear or quadratic relationships existing between WCM and firm performance (BanosCaballero, Garcia-Teruel \& Martinez-Solano, 2014; Afrifa \& Padachi, 2016). The term "quadratic" is borrowed from economics to explain a relationship that is rarely linear. In other words, the term quadratic is employed in this study to describe the type of investment in working capital that is nonsequential and harbours the propensity to deviate.

In the context of Nigeria, a key problem affecting firms has been several economic crises, which has resulted in high liquidity issues for firms. Typically, Nigerian economic crises can be linked to its heavy dependence on the oil sector. Consequently, the economy has not performed to its full potential relative to the Nigeria's enormous endowments of natural and mineral resources (Sanusi, 2010). For instance, the country has the sixth largest gas reserves in the world and has the eighth largest crude oil reserves as well. In fact, mineral resources are said to account for $80 \%$ of the revenues of the Nigerian government (Sanusi, 2010). However, over dependence on petroleum 
resources has made the Nigerian economy vulnerable to the vicissitudes of periodic disruptions of the oil market. These disruptions have often led to falling oil revenue, which has placed heavy pressure on the country's external accounts. In addition, the deleterious performance of the economy has resulted in the lowering of investor confidence, exchange rate volatility, stagnating government expenditures and a significant rise in inflation rates (Sayne \& Hruby, 2016). Moreover, foreign direct investment (FDI) fell by 37\%, while capital inflows were reduced by $75.7 \%$ around the second quarter of 2016 (Mitchell, 2016).

The consequences of these economic challenges are entrenched in the level at which the revenue of firms in Nigeria and the growth of their investments and liquidity have been negatively affected. In other words, most companies in the country are now encountering major financial challenges that are adversely affecting their operational activities. Furthermore, the current pitfalls in the WCM of firms in Nigeria can also be linked to the recent policy of the Central Bank of Nigeria $(\mathrm{CBN})$ on forex allocation to raw material requirements. The CBN ceased to allocate forex to firms for acquiring raw materials which are considered essential to the continued survival of firms (Nnorom, 2015; Adebimpe \& Ekubiat, 2015).

In general, the philosophy of working capital management is meant to generate adequate liquidity through free cash flow. In addition to that, such a framework also guarantees smooth and continued operational activity. To understand the importance of working capital management, providing a definition of the concept is important. Filbeck and Krueger (2005, p. 11), for example, defined "working capital as the difference between resources in cash or readily convertible into cash (current assets) and organizational commitments for which cash will soon be required (current liabilities)." Therefore, working capital is the difference between current assets and current liabilities. This indicates that WCM is time-bound and reflects liquidity through the process of cash conversion to raw materials, to finished goods, to sales and finally to ready cash again. To enhance the performance of firms, the money conversion process must be completed within a material time.

As such, WCM is vital to firms in several ways, some of which involve significant roles in enhancing performance and shareholders' value (Deloof, 2003; Filbeck \& Krueger, 2005; Makori \& Jagongo, 2013). Underscoring this point, Orobia, Padachi, and Munene (2016) noted that poor WCM affects the growth and rate of survival of firms and their overall economic development. However, the mixed findings in the literature (Makori \& Jagongo, 2013; Salman, Folajin, \& Oriowo, 2014; Yazdanfar \& Öhman, 2014) suggest that the effect of working capital management on firm performance is inconsistent. Thus, the effect of WCM on firm performance can be either linear or quadratic and either positive or negative, depending on other relevant variables and situational factors.

This stance has influenced previous researchers to examine a linear relationship between WCM and firm performance (Deloof, 2003; Lazaridis \& Tryfonidis, 2006; Charitou, Lois \& Budi, 2012; Ademola, 2014; Wasiuzzaman, 2015; Sharma \& Kaur, 2016). However, Martinez-Sola, Garcia-Teruel, and Martinez-Solano (2014), Nha and Loan (2015), Pais and Gama (2015) and Afrifa and Padachi (2016) opined that the relationship between WCM and firm performance is non-linear and should, therefore, be examined through a quadratic model (Afrifa \& Padachi, 2016). This recommendation is yet to receive notable attention from researchers especially in the context of Nigerian economy and Africa at large.

Therefore, this study aims at determining the quadratic relationship between WCM and firm performance in Nigeria, with a focus on large firms in lieu of SMEs, which have been the concern of prior studies (Martinez-Sola et al., 2014; Pais \& Gama, 2015; Afrifa \& Padachi, 2016). This paper is therefore structured as follows: section two of the paper reviews the relevant literature relating to WCM. Section three discusses the methodology used and presents the results of the analyses while section four concludes the paper. 


\section{Literature Review}

The relationship between working capital management and firm performance has been extensively studied from different viewpoints. Some have viewed WCM from the perspective of its influences on firm performance (Deloof, 2003; Lazaridis \& Tryfonidis, 2006; Owolabi \& Alu, 2012; ElMaude \& Shuaib, 2016). Others have provided evidence that low and high investment levels in working capital management have benefits and costs, indicating that investments in WCM have characteristics different from the linearity assumptions of most studies (Banos-Caballero et al., 2014; Nha \& Loan, 2015; Pais \& Gama, 2015; Afrifa \& Padachi, 2016). These studies have resulted in mixed findings, which suggest the need for further studies to confirm the presumption regarding WCM investment levels. For example, Deloof (2003), Charitou, Elfani and Lois (2010), Napompech (2012), Owolabi and Alu (2012), Tauringana and Afrifa (2013), Iqbal et al. (2014), Wasiuzzaman (2015) and Pais and Gama (2015) found a statistically significant relationship between working capital management variables and measures of performance.

Deloof (2003) evaluated the impact of working capital management on the profitability of Belgian firms using a total observation of 1,009 firms between 1992 and 1996. The study found a significant and negative relationship between all the working capital management variables (account receivables, accounts payable, inventory and cash conversion cycle) and gross operating income (GOI). Similarly, Charitou et al. (2010) examined the effect of WCM on the profitability of 43 firms in emerging markets from 1998 to 2007. On the other hand, Owolabi and Alu (2012) determined the effectiveness of WCM and profitability using five manufacturing firms listed on the Nigerian Stock Exchange between 2006 and 2010. While Napompech (2012) used 255 listed firms on the Thailand Stock Exchange between 2007 and 2009 to evaluate the effect of WCM on profitability of Thai firms. Tauringana and Afrifa (2013) used 133 firms in the United Kingdom between 2005 and 2009 to determine the relative importance of WCM and its components on SME's profitability of Alternative Investment Market (AIM) listed firms. Iqbal (2014) also determined the relationship between WCM and profitability of Pakistan listed firms. Wasiuzzaman (2015) also used a sample of 160 manufacturing firms to investigate the influence of WCM on firms in Malaysia between 2005 and 2010. Pais and Gama (2015) studied the influence of WCM on 6,063 non-financial SME's profitability of Portuguese firms. These studies concluded that minimizing investments in WCM enhances the performance of firms.

However, several other studies have contradicted these findings. Sharma and Kumar (2011) investigated the effect of WCM on 263 non-financial firms in India from 2000 to 2008. Their findings revealed that days accounts payable and inventory management days were negative and significantly related to ROA while accounts receivable and cash conversion period were positively associated with ROA. They concluded that good management practices of working capital are crucial in providing liquidity and enhancing firms' profitability. Moreover, Makori and Jagongo (2013) evaluated the impact of WCM on the performance of ten firms listed on Nairobi Securities Exchange between 2003 and 2012. They found that the accounts receivable period and the cash conversion cycle were negatively related to firm performance while the inventory and accounts payables period showed a positive and significant relationship to firm performance in Nairobi. All their results were statistically significant except for accounts receivable period. They concluded that the survival of firms depends largely on how effectively and efficiently WCM components are managed. El-Maude and Shuaib (2016) empirically investigated the association of WCM and the performance of ten listed Food and Beverages firms in Nigeria between 2010 and 2014. The results of their analysis revealed that a negative and insignificant and a significant and negative relationship existed between the cash conversion cycle and accounts receivable with profitability respectively. Inventory days were positive but statistically not significant while accounts payable was positive and statistically significant in relationship to profitability. The findings of these studies reflect that the relationship between WCM variables and a firm's performance is uncertain. This uncertainty may also be linked 
to the findings of prior studies suggesting that the effect of WCM on firm performance depends on the optimal level of investment in working capital.

Optimal working capital levels influence the liquidity and profitability of firms (Bolek, 2013). WCM provides short-term funds and guarantees smooth operational activities for firms, and liquidity management is crucial in good times and takes pre-eminence in troubled times (Eljelly, 2004). Liquidity is a necessary condition that mitigates against bankruptcy. Liquidity management has been defined as involving the "efficient planning and controlling of current assets and current liabilities in such a manner that eliminates the risk of the inability to meet short-term obligations, on one hand and avoid excessive investment on the other hand" (Eljelly, 2004, p. 1). Hence, maintaining higher liquidity reduces the risk of default and insolvency, but high liquidity tends to reduce the profitability of firms as it may constitute idle resources (Eljelly, 2004). Thus, the inference can be made that appropriately ensuring a balance between liquidity and returns to their investments is important for firms. The benefits and costs associated with holding a large inventory supports the primary argument of Afrifa and Padachi (2016), suggesting that a non-linear (quadratic) relationship may account for the relationship between WCM and firm performance. Aggressive and conservative working capital policies also support the view of a non-linear relationship (Afrifa \& Padachi, 2016; Bolek, 2013; Tauringana \& Afrifa, 2013).

The assumptions of a non-linear (quadratic) relationship between WCM and firm performance have been examined in different countries (Banos-Caballero et al., 2014; Nha \& Loan, 2015; Pais \& Gama, 2015; Afrifa \& Padachi, 2016). Banos-Caballero et al. (2014) investigated the association between WCM, corporate performance and financial constraints amongst non-financial firms in the United Kingdom between 2001 and 2007. Their study adopted the alternate measure of working capital management (Net Trade Cycle) that Shin and Soenen (1998) developed. They noted that managers traditionally adopt a lower level of working capital to increase investments in WCM to enhance their sales and enjoy discounts for early payments from suppliers. But, this basic method leads to a level of working capital at which higher investments begin to yield negative returns resulting from additional interest expenses and to create higher chances of credit risk for firms and a higher probability of bankruptcy (illiquidity). Their findings suggest the presence of an inverted Ushaped relationship between working capital management and corporate performance and imply that an optimal level of investment in working capital management exists that balances costs and benefits and maximizes firm performance. In a similar study, Nha and Loan (2015) used a different model to confirm the U-shaped relationship between WCM and firm value. They used 450 nonfinancial companies listed on Vietnamese Stock Market between 2006 and 2014. Nha and Loan (2015) used a non-common measure of WCM defined as [(Cash and equivalents + Short-term investments + Inventories + Accounts receivables) - Accounts payables] / [Total assets - Cash and equivalents]. They found that an optimal level exists at which investments in working capital will maximize firm value and deviation from such an optimal level of investments in working capital management could reduce firm value. Thus, this finding indicates that a non-linear relationship exists between WCM and firm performance.

Meanwhile, Pais and Gama (2015) used a sample of 6,063 Portuguese SMEs between 2002 and 2009. Their robustness test confirmed that a non-linear relationship exited between WCM and profitability of SMEs in Portuguese. Pais and Gama (2015) and Lyngstadaas and Berg (2016) provided evidence of a non-linearity relationship in their study through the robustness test conducted. Lyngstadaas and Berg (2016) evaluated the effect of WCM on the performance of 21,075 SMEs from Norway between 2010 and 2013. Their results confirm the findings of Banos-Caballero et al. (2014), Nha and Loan (2015) and Pais and Gama (2015). Afrifa and Padachi (2016) presented a more robust model to explain the relationship between the WCM level and 160 Alternative Investment Market (AIM) SMEs between 2005 and 2015. Their study extended the models of BanosCaballero et al. (2014) and Nha and Loan (2015) by using a more conventional working capital management proxy - cash conversion cycle defined as [(Inventory/Cost of Sales) x $365+$ (Accounts 
Receivable/Sales) x 365 - (Account Payable/Cost of Sales) x 365]. Using three different measures of profitability, their result confirmed the existence of an optimal level of WCM that maximizes SME's profitability. This generated two obvious dimensions of the non-linear relationship. First, it confirmed that the relationship between WCM and profitability is non-linear or quadratic and that an optimal working capital level exists that maximizes profitability. Second, the study confirmed that deviations from this optimal level result in reducing firm profitability.

Thus, assorted studies have shown that a quadratic relationship exists between WCM and firm performance but most previous studies (Banos-Caballero et al., 2014; Nha \& Loan, 2015; Pais \& Gama, 2015; Afrifa \& Padachi, 2016; Lyngstadaas \& Berg, 2016) examined this relationship with respect to SMEs. While the study of Nha and Loan (2015) evaluated listed firms, it used a proxy different from the traditional WCM proxies that have been utilized (for example, the net trade cycle, and cash conversion cycle and accounts payables). Hence, this usage may reduce the reliability of the proxy and therefore affect the generalization of their results.

Given that previous studies have contributed to the overall understanding of the non-linear relationship of WCM (but with much concentration on SMEs), the present study becomes imperative against the backdrop that very few attempts have been made to test this assumption using the CCC for listed firms in both developed and developing countries. Also, given the limited studies undertaken in relationship to the non-linear relationship between WCM and firm's performance as articulated in the preceding paragraphs, it is not surprising that existing literature on WCM in Nigeria and Africa at large lacks in-depth understanding of the subject. Hence, this current study intends to fill this gap by determining the quadratic relationship between WCM and performance of listed firms in Nigerian. The study adopted the metrics of CCC as a comprehensive dimension of working capital management in its evaluation. Moreover, given the liquidity challenges and increasing decline in the performance of firms in Nigeria, the underlying assumption of the quadratic framework will benefit firms from the region, particularly in their operational activities. The findings may also help determine the implications of either excess or inadequate level of investments in WCM. Thus, the findings of this study will also usher in a new research dimension for scholars in both developed and developing countries and most particularly the African continent.

Drawing upon the above discussion and arguments regarding WCM and firm performance, the following hypotheses are posited.

$\mathrm{H}_{1}$ : There is a quadratic relationship between WCM and firm performance.

$\mathrm{H}_{2}$ : Deviation from the optimal WCM investment level affects firm performance.

\section{Methodology}

The data for this study were drawn from listed firms on the Nigerian Stock Exchange (NSE) for the period 2007 to 2015. The choice of listed firms is consistent with Lazaridis and Tryfonidis (2006) and Mathuva (2010) who opined that listed companies or firms present more reliable financial data, as their financial reports are mandated by law to be published in their annual reports, and an independent auditor must examine such reports. This reduces bias and material misstatement that may lead to wrong inferences.

A total of 124 firms were listed on the NSE (excluding financial firms) during the period. Following Tauringana and Afrifa (2013) and Afrifa and Padachi (2016) financial firms (banks and insurance firms) were excluded because of the peculiar nature of their activities and the definition of working capital that they have adopted is inconsistent with the definition applied in this study (Lazaridis \& Tryfonidis, 2006). The initial sample of this study comprised 95 firms. This was narrowed down to 75 firms (representing 93\%) due to incomplete information for these periods. Finally, a sample of 75 firms was considered for the periods 2007 to 2015, which resulted in 675 firmyear observations.

The quantitative data resulting from the sample was analysed using the balanced panel data framework. Panel data permits control for individual heterogeneity of the model (Hsiao, 2003). 
According to Baltagi (2005), panel data give more informative data, guarantee more reliability, have more degrees of freedom and are much more efficient. Given the extensive usage of return on assets (ROA) and return on equity (ROE) in WCM literature, this study employed these measures for the dependent variables. The usage will enable comparison of the results in this current study with those of previous findings. The independent variables are cash conversion cycle (CCC) and cash conversion cycle square (CCC${ }^{2}$ ). The inclusion of cash conversion square (CCC $\left.{ }^{2}\right)$ is consistent with Afrifa and Padachi's (2016) study, which was aimed at determining the costs and benefits associated with holding high/low level investments in working capital management. This format will similarly be used to determine the quadratic relationship and implications of deviating from optimal working capital levels. The three most-used control variables in WCM studies were also adopted to control for the differences across the sampled firms. They are: 1) firm size, 2) sales growth and 3) the financial debt ratio. The variables are shown in Table 3.1.

\section{Table 3.1}

\begin{tabular}{|c|c|c|c|}
\hline Variables & Acronym & Definition & Source (s) \\
\hline Return on Assets & ROA & $\begin{array}{l}\text { Profit After Tax Divided by Total } \\
\text { Assets. }\end{array}$ & $\begin{array}{l}\text { Afrifa and Padachi } \\
(2016)\end{array}$ \\
\hline Return on Equity & ROE & $\begin{array}{l}\text { Profit After Tax Divided by } \\
\text { Shareholder's Equity. }\end{array}$ & $\begin{array}{l}\text { Afrifa and Padachi } \\
(2016)\end{array}$ \\
\hline $\begin{array}{l}\text { Cash Conversion } \\
\text { Cycle }\end{array}$ & $\mathrm{CCC}$ & $\begin{array}{l}\text { [(Account Receivable } \times 365 / \text { Sales }) \\
+ \text { (Account Payable } x \\
\text { 365/Purchases) - (Inventory } x \\
\text { 365/Cost of Sales)]. }\end{array}$ & $\begin{array}{l}\text { Deloof (2003), Afrifa } \\
\text { and Padachi (2016) }\end{array}$ \\
\hline $\begin{array}{l}\text { Cash Conversion } \\
\text { Cycle Square }\end{array}$ & $\mathrm{CCC}^{2}$ & $\begin{array}{l}\text { Cash Conversion Cycle x Cash } \\
\text { Conversion Cycle. }\end{array}$ & $\begin{array}{l}\text { Afrifa and Padachi } \\
(2016)\end{array}$ \\
\hline Firm Size & FSz & Natural Log of Sales. & Deloof (2003) \\
\hline Sales Growth & SGt & $\begin{array}{l}\text { This Year's Sales - Previous Year's } \\
\text { Sales / Previous Year's Sales. }\end{array}$ & Deloof (2003) \\
\hline Financial Debt Ratio & FDR & Financial Debt/Total Assets & Deloof (2003) \\
\hline
\end{tabular}

Several measures were employed to achieve the assumption of normality in this study. The data for this study were winsorized at 3\% to deal with normality and outlier observations. The winsorization estimates reduce the estimator's variances in regression better than direct estimation. As Dehnel (2014, p.98) noted, "the general idea of winsorization is that if an observation exceeds a present cut-off value, then the observation is replaced by that cut-off value or by a modified value closer to the cut-off value". This is consistent with the method that Kieschnick et al. (2006) and Afrifa and Padachi (2016) applied. By winsorizing data, outliers' values are reduced so that the result produces an insignificant estimated bias in the characteristics of the estimates.

Moreover, auto/serial correlation and heteroskedasticity tests were conducted. The results of the Wooldridge test for autocorrelation in the panel revealed an insignificant $p>$ value (not significant at $5 \%$ ), suggesting no presence of auto/serial correlations in the model. Additionally, the Breush-Peagan and Modified Wald tests for group-wise heteroskedasticity test were conducted to determine the presence of heteroskedasticity. The results show that the null hypotheses were rejected, as the p-values were all significant at the 5\% level. This suggests the presence of heteroskedasticity in the models. This means that the variances in the models are constant. To remedy this problem, the study applied the option of the robust approach in all the models. The Hausman specification test was also conducted to make a choice between the Fixed Effect (FE) and the Random Effect (RE) (Green, 2008). The results of Hausman specification test were all significant indicating p-values of 0.0477 and 0.0194 for the ROA and ROE models respectively. This leads to the 
conclusion that FE was the appropriate model for this study. The various models are estimated as follows:

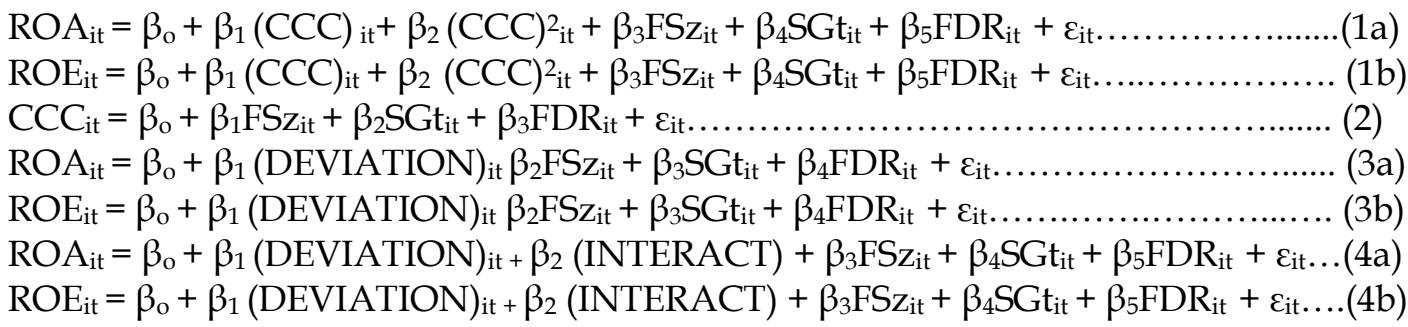

The above models were estimated to determine the quadratic relationship between investment in working capital management and firm performance in Nigeria. As defined in the summary of the measurement variables (Table 3.1), ROA and ROE are dependent variables measuring firm performance. CCC is the main independent variable used to measure low-level investments in WCM while CCC ${ }^{2}$ measures high-level investment in WCM. FSz, SGt and FDR are control variables defined in Table 3.1. DEVIATION is the absolute value of the residuals derived from equation 2 while INTERACT is defined as the "above-optimal*DEVIATION". The subscript $\mathrm{i}$ indicates individual firm, $t$ indicates the time while $\varepsilon$ denotes the error term.

\section{Results and Discussion}

Table 3.2 shows the descriptive statistics of the variables considered in this study. According to the Table, ROA had a mean value of $5.39 \%$ with minimum and maximum values of $-20.0 \%$ and $28.6 \%$ respectively. ROE on average was $23.3 \%$ with minimum and maximum values of $0.006 \%$ and $97.6 \%$ respectively. The descriptive statistics of the two dependent variables (ROA and ROE) had wide variations in value, and the differences exhibited in these variables makes their inclusion in the study worthwhile. The CCC had a mean value of 98 days with minimum and maximum values of 121.16 days and 469.8 days respectively. This is similar to 99.5391 days of CCC found in Karaduman et al.'s (2010) study. This is important because a gap of 98 days implies the period firms would source for funding while they await recovery of cash from sales. A longer number of days for CCC is suggestive of inefficient financial policies by firms. This conclusion is supported by the clear consensus in WCM literature that a longer CCC may lead firms into a cash-trap situation requiring external funding. In turn, a cash-trap situation will impact negatively a firm's liquidity position and, its ability to deliver on market expectations and enhance performance.

The mean values for firm size (FSz), sales growth (SGt) and financial debt ratio (FDR) were $9.88,13.26$ and 57.31 respectively. The skewness ranged between -0.064 and 1.19 while the Kurtosis ranged from 2.31 to 5.81 . The skewness and kurtosis indicate that the data for this study were normally distributed as they fell within the threshold value of $+/-3$ for skewness and $+/-10$ for kurtosis respectively as Kline (2011) suggested.

Table 3.2

Summary of descriptive statistics

\begin{tabular}{lrlrrrr}
\hline Stats & \multicolumn{1}{l}{ ROA } & ROE & \multicolumn{1}{c}{ CCC } & \multicolumn{1}{c}{ FSz } & \multicolumn{1}{c}{ SGt } & \multicolumn{1}{l}{ FDR } \\
\hline Mean & 0.05392 & 0.23321 & 98.03848 & 9.87868 & 0.13259 & 0.57314 \\
Median & 0.05113 & 0.15712 & 69.81130 & 9.86017 & 0.08566 & 0.56139 \\
Min & -0.20034 & 0.00006 & -121.16550 & 8.26919 & -0.54096 & 0.07676 \\
Max & 0.28572 & 0.97583 & 469.85650 & 11.26919 & 1.26439 & 1.39987 \\
Skewness & -0.20550 & 1.66243 & 1.21795 & -0.06385 & 1.19217 & 0.77529 \\
Kurtosis & 4.09724 & 5.48206 & 4.88086 & 2.30882 & 5.80924 & 4.23238 \\
\hline
\end{tabular}

Source: Author's computation.

Notes: $\mathrm{ROA}=$ return on assets, $\mathrm{ROE}=$ return on equity, $\mathrm{CCC}=$ cash conversion cycle, $\mathrm{FSz}=$ firm size, $\mathrm{SGt}=$ sales growth, and FDR $=$ financial debt ratio. 
Table 3.3 presents the correlation matrix for the variables of the study. The values were derived from a total firm-year observation of 675 . The correlation between ROA and ROE was 0.1152 and was statistically significant at $1 \%$. The correlation between CCC and ROA was negative with a value of -0.1643 and statistically significant at $1 \%$. Similarly, CCC was also negatively correlated with ROE, had a coefficient value of -0.1190 , and was statistically significant at $1 \%$. This indicates that a shorter CCC is associated with higher performance. The result of the correlation is consistent with the WCM assumption which states that shorter CCC creates less need for external financing and reduces the risk of bankruptcy (Deloof, 2003; Nobanee et al., 2011). This implies that firms can realize cash in a timely manner, which is essential for enhancing their performance. Furthermore, firm size (FSz) was positively correlated with both ROA and ROE. The coefficients were 0.3264 and 0.1162 respectively, and they were both statistically significant at $1 \%$. The positive relationship explains that large firms enjoy advantages over small firms. For example, large firms enjoy greater discounts and other privileges due to their large consumption (Pervan \& Visic, 2012). Large firms also have a longtime experience, which promotes wider market acceptability and the adoption of best practices that yields competitive advantages.

Table 3.3

Variables Correlation Matrix

\begin{tabular}{lllllll}
\hline Variables & ROA & ROE & CCC & FSz & SGt & FDR \\
\hline ROA & 1.0000 & & & & & \\
ROE & $0.1152^{* * *}$ & 1.0000 & & & & \\
CCC & $-0.1643^{* * *}$ & $-0.1190^{* * *}$ & 1.0000 & & & \\
FSz & $0.3264^{* * *}$ & $0.1162^{* * *}$ & $-0.3418^{* * *}$ & 1.0000 & & \\
SGt & $0.2276^{* * *}$ & -0.0073 & $-0.0960^{* *}$ & $0.0647^{*}$ & 1.0000 & \\
FDR & $-0.2183^{* * *}$ & $0.3542^{* * *}$ & -0.0290 & $0.0751^{*}$ & -0.0259 & 1.0000 \\
\hline
\end{tabular}

Source: Author's computation.

Notes: $\mathrm{ROA}=$ return on assets, $\mathrm{ROE}=$ return on equity, $\mathrm{CCC}=$ cash conversion cycle, $\mathrm{FSz}=$ firm size, $\mathrm{SGt}=$ sales growth, and FDR $=$ financial debt ratio.

Sales growth (SGt) was found to be positively correlated with ROA and statistically significant at $1 \%$ but negatively correlated with $\mathrm{ROE}$, though the coefficient was insignificant. Sales growth traditionally is expected to be positively related to performance, but, given the challenging financial crisis in Nigeria, the negative and insignificant correlation between SGt and ROE was not surprising. The results also show that FDR was negative and significantly correlated with ROA. The coefficient was -0.2183 and significant at $1 \%$. With regards to ROE, the coefficient of FDR was positive (0.3542) and significant at $1 \%$. From Table 3.3 above, the correlations amongst the remaining independent and control variables did not differ significantly from expectations as the highest value was (0.3542) between FDR and ROE. The correlation matrix, therefore, shows no multicollinearity problem, as the coefficients are below the threshold of 0.8 that Field (2009) suggested. Furthermore, the mean value of variance inflation factor (VIF) of 2.43 confirmed that the variables in this study were not highly correlated.

\section{Determination of the Quadratic Relationship}

Table 3.4 presents the results of the quadratic relationship between WCM and firm performance. As proposed in Model 1, two effects of WCM investment levels were created. The CCC represented low investment levels while $\mathrm{CCC}^{2}$ represented high investment levels in WCM. This was done to determine the quadratic relationship and consequently the optimal level of investment. To confirm this relationship, the coefficients $\beta_{1}$ and $\beta_{2}$ are expected to be either positive and negative or negative and positive respectively to confirm the effect. The results in Table 3.4 show that, the $\mathrm{R}^{2}$ for ROA was $10 \%$ while the $\mathrm{R}^{2}$ for $\mathrm{ROE}$ was $9 \%$. The $\mathrm{R}^{2} \mathrm{~S}$ indicate that the models explained about $10 \%$ and $9 \%$ of the variations in ROA and ROE respectively. The F-probability was statistically significant at $1 \%$ for both ROA and ROE. These show that jointly the models are fit in predicting firm 
performance. The results of CCC and $\mathrm{CCC}^{2}$ were consistent with expectations. The CCC was negatively and insignificantly associated with both ROA and ROE. The coefficients of CCC were 0.0000919 and -0.0001577 for ROA and ROE respectively while the $\mathrm{CCC}^{2}$ was associated positively with both ROA and ROE. The coefficient value of ROA was 0.000000223 and not statistically significant. ROE also had an insignificant coefficient value of 0.000000312 . The results of ROA and ROE were statistically not significant because their p-values were greater than $10 \%$. This is not surprising as it reflects the consequences of both high inflation and interest rates that firms in Nigeria experience.

\begin{tabular}{|c|c|c|}
\hline Variables & $\operatorname{ROA}$ & ROE \\
\hline $\operatorname{CCC}^{2}$ & $0.000000223(1.08)$ & $0.000000312(0.64)$ \\
\hline$S \in t$ & $0.0555814(3.73)^{x+x}$ & $0.0075271(0.26)$ \\
\hline FDIR & $-0.0469117(-2.22)^{x-x}$ & $0.2244374(3.56)^{x-x+x}$ \\
\hline Constant & $-0.081464(-0.49)$ & $0.737274(2.08)^{*}$ \\
\hline F>Prob & O.0OOO & 0.0000 \\
\hline rlho & 0.48977 & 0.44312 \\
\hline Observations & 675 & 675 \\
\hline Feteroskedasticity| & $57967.81(0.0000)$ & $35957.94(0.0000)$ \\
\hline Serial Correlation & $1.636(0.2049)$ & $22.931(0.0000)$ \\
\hline
\end{tabular}

The results are in line with expectations. The results indicated that CCC was negatively related with ROA and ROE. The results indicate that realizing cash early improves firm performance. This is in line with the findings of Deloof (2003) and Lazaridis and Tryfonidis (2006). They stated that the inverse relationship between CCC and profitability suggests management efficiency in realizing cash early enough and avoiding the danger of a cash trap. Hence, the results of this current study demonstrate a level of efficiency that leads to sustainable performance of firms. Consistently, the negative relationship between CCC and ROA and ROE also shows that investment in WCM increases firm performance to a "point" at which further (high) investments in WCM (denoted by $\mathrm{CCC}^{2}$ ) will begin to reduce firm performance. This is evident in the positive relationship between $\mathrm{CCC}^{2}$ and ROA and ROE. It signifies longer periods of the cash conversion cycle. The longer gap indicates the period that a firm uses to source for external funding to maintain operational activity levels. Integral to this current discussion is that a lower level of investment in WCM increases firm performance to a point at which a higher-level investment in WCM will lead to gross underperformance. This result is consistent with the findings of Banos-Caballero et al. (2014), Nha and Loan (2015), Pais and Gama (2015), Afrifa and Padachi (2016) and Lyngstadaas and Berg (2016) who clearly provided evidence that the relationship between WCM and firm performance is quadratic.

Other variables included in the analysis to control for the differences amongst firms are firm size, sales growth and financial debt ratio. Firm size was positively related to ROA but not statistically significant. Related to ROE, the relationship between a firm's size and ROE was significant and negative. Sales growth on the other hand was positively associated with both ROA and ROE. However, the coefficient of ROA was statistically significant at $1 \%$ while the coefficient of ROE was statistically insignificant. The FDR was negatively associated with ROA. The coefficient was significant at $5 \%$ while the coefficient of the relationship between FDR and ROE was positive and statistically significant at $1 \%$.

\section{Effect of Deviation from Optimal Working Capital Investment Level}

How a firm manages investment in working capital is a major issue in this paper. That is how WCM impacts a firm's liquidity position, profitability and its ability to sustain growth. It is evident 
from Table 3.4 that the relationship between WCM and firm performance was quadratic. The quadratic relationship suggests a lower investment boundary and higher investment boundary for WCM that inevitable leads to the conclusion that an optimal level of WCM investment exists that maximizes firm performance.

Hence, this section determines the effect of deviation from this "optimal level" of investment in WCM by considering Models 3. In Models 1, a quadratic relationship was established, and this relationship reflects on the potential impacts of working capital in improving firm performance to an optimal point, at which further investments reduce performance. Following Martinez-Sola et al. (2014), Nha and Loan (2015) and Afrifa and Padachi (2016), CCC and CCC ${ }^{2}$ were eliminated in Models 1 and replaced with the residual estimated from Model 2 by making CCC the dependent variable. Several steps were followed to determine the effect of deviation.

\begin{tabular}{lcc} 
Table 3.5 & & \\
Determination of Deviation from Optimal Level of WCM Investments \\
\hline Variables & ROA & ROE \\
\hline DEVIATION & $-0.028702(-4.52)^{* * *}$ & $-0.0133325(-1.09)$ \\
FSz & $-1.440642(-4.65)^{* * *}$ & $-0.740557(-1.25)$ \\
SGt & $-.7019604(-4.44)^{* * *}$ & $-0.3438182(-1.12)$ \\
FDR & $-0.1174142(-4.38)^{* * *}$ & $0.192707(2.38)^{* *}$ \\
Constant & $17.26001(4.65)^{* * *}$ & $8.791255(1.23)$ \\
R2 & 0.1028 & 0.0893 \\
F-value & 17.07 & 14.6 \\
F>Prob| & 0.0000 & 0.0000 \\
rho & 0.48639 & 0.44840 \\
Observations & 675 & 675 \\
Source: Author's derivation. & & \\
Notes: Variables results begin with their coefficients, t-statistics are in parenthesis \\
while ******* denote significance levels at 10\%, 5\%, and 1\% respectively. Results \\
were obtained using the FE model with robust cluster estimate.
\end{tabular}

Firstly, the residuals estimated from Model 2 were obtained and substituted with CCC and $\mathrm{CCC}^{2}$ in Model 1 ( $\mathrm{a} \& \mathrm{~b}$ ). Secondly, the residual's absolute values were determined from equation 2. The absolute values of the residual are called deviation. Thirdly, deviation was included in Models 3 $(\mathrm{a} \& \mathrm{~b})$, as the main independent variable to determine if deviation from the optimal investment level of WCM affects the performance of firms. Consistent with Nha and Loan (2015) and Afrifa and Padachi (2016), there is the assumption that in Models 3 (a \& b), the coefficients of the deviation will be negative and less than zero $(\beta<0)$. This will indicate a negative relationship between deviations from optimal investment level of WCM and firm performance. As expected, Table 3.5 revealed that the coefficients of deviation were negatively associated with both measures of firm performance ROA and ROE. The coefficient of ROA was statistically significant at $1 \%$ while the coefficient of ROE was not statistically significant. The negative relationship between deviation and firm performance confirms the quadratic relationship of WCM and implies that deviation from an optimal investment level of WCM affects firm profitability negatively. These results, however, did not show if deviation either higher or lower (above or below the optimal level) affected firm profitability.

To determine whether deviations in either way (above or below) affected profitability, Models 4 was introduced. Model 4 (a \& b) advances over Model 3 by including an Interaction Term. The aim is to determine the effect of deviation below (negative) or above (positive) the optimal investment level in WCM on firm performance. Following Afrifa and Padachi (2016), the term Interact was introduced and defined as Above Optimal*Deviation. Above optimal is described as a dummy variable that takes the value of 1 for a positive residual estimated in Model 2 and 0 if otherwise. Table 3.6 presents results of Model 4 (a \& b). In line with the studies of Nha and Loan (2015) and Afrifa and Padachi (2016), the expectation was that the coefficient of Deviation $\left(\beta_{1}<0\right)$ would be less than 0 and the coefficient of Deviation + Interact $\left(\beta_{1}+\beta_{2}<0\right)$ also less than 0 . 
Table 3.6

Effect of Deviation from Optimal Level of WCM Investments on Firm Performance

\begin{tabular}{lcc}
\hline Variables & ROA & ROE \\
\hline DEVIATION & $-0.0570636(-4.58)^{* * *}$ & $-0.0328143(-1.30)$ \\
INTERACT & $0.0567238(4.65)^{* * *}$ & $0.0210581(0.77)$ \\
FSz & - & $-4.104798(-0.56)$ \\
SGt & $0.0475753(2.96)^{* * *}$ & $-0.2990479(-0.48)$ \\
FDR & $-0.0456682(-2.11)^{* *}$ & $0.1950883(2.08)^{* *}$ \\
Constant & $0.1072857(2.95)^{* * *}$ & $14.2046(0.55)$ \\
R $^{* *}$ & 0.1028 & 0.0901 \\
rho & 0.48639473 & 0.43475858 \\
Observations & 675 & 675
\end{tabular}

Source: Author's derivation.

Notes: Variables results begin with their coefficients, $t$-statistics are in parentheses while $*, * * * *$ denote significance levels at $10 \%, 5 \%$, and $1 \%$ respectively. Results were obtained using the FE model with a robust cluster estimate

The results in Table 3.6 show that Deviation was negatively associated with both ROA and ROE. The coefficient of ROA was statistically significant at $1 \%$ while the coefficient of ROE was statistically insignificant. Conversely, interact was positively associated with both ROA and ROE. The coefficient of ROA was significant at $1 \%$ while the coefficient of ROE was statistically insignificant with respect to Interact. Mathematically, the expectation was that the coefficients of $\beta_{1}<$ 0 and $\beta_{1}+\beta_{2}<0$ and would confirm the effect of Deviation. In column 1 (ROA model), the coefficients of $\beta_{1}$ was $<0(-0.0570636)$ while $\beta_{1}+\beta_{2}$ was $<0(-0.0570636+0.0567238=-0.0003398)$. In column 2 (ROE model), the coefficients of $\beta_{1}$ was $<0(-0.0328143)$ while $\beta_{1}+\beta_{2}$ was $<0(-0.0328143+$ $0.0210581=-0.0117562)$. These results support the study's hypothesis, which stated that Deviation from an optimal level of investment in working capital would negatively affect firm performance. This is indicated in the sum of the coefficients values of Deviation and Interact that yielded a negative value, suggesting that deviation have a negative effect on firm performance.

The relationship between WCM and firm performance has been widely presumed to be linear, but this paper provided evidence that the relationship is quadratic. This means that either a low-level or a high-level investment in working capital has implications with respect to the reduction of firm performance and threatens a firm's sustainability. Integral to the potential impacts of either a low or a high-level investment in working capital is the conclusion that an optimal level exists for maximizing firm performance. Thus, deviations, in either direction from an optimal level of investment affect firm performance. This study, therefore, argues that understanding the variability of investment in WCM will greatly influence firm performance. This is noteworthy because investments in WCM clearly show a lack of consistency. For instance, Samiloglu and Demigunes (2008) argued that investment in WCM demonstrates a high level of complexity as both excessive and inadequate WCM have an adverse effect on firm performance. While excessive WCM suggests idle funds and inefficiency, inadequate WCM relates to the inability of a firm to meet its short-term, maturing obligations. This inability has the consequence of limiting the chances of firms taking advantage of favourable market conditions as they arise and impairs the reputation of firms. Such a state leads to some deprivations for firms.

In a related opinion, Afza and Nazir (2007) argued that investment in WCM can be categorized into aggressive and conservative policies. They described aggressive WCM policy as a technique adopted to deploy minimal investments in current assets as a proportion of total assets. While a conservative WCM policy places great importance on a high proportion of investments in liquid assets, both conservative and aggressive financing policies have effects on the rate of return of a firm's investments. Arising from the effects of these policies, Salawo (2007) suggested that a combination of both aggressive and conservative policies would strengthen productivity and enhance firm performance. In support of this argument, Deloof (2003), Tauringana and Africa (2013) and many others have both stated that low-level and high-level investments in working capital 
management have benefits and costs. Thus, the variability of WCM financing policies and their consequences demonstrated the need for this study. However, different results have been found about the non-linearity of WCM investment levels (Nha \& Loan, 2015; Afrifa \& Padachi, 2016), but the results of this study provide an important insight that would help guarantee firm performance, particularly in the Nigerian context.

\section{Conclusion}

This study examines the quadratic relationship between WCM and performance of nonfinancial firms in Nigeria. The fundamental finding of this study is that both high and low investments in working capital have implications for firm performance. The findings from the study suggest that the relationship between WCM and firm performance is quadratic and not linear. The result also shows that an optimal investment level exists in working capital, which maximizes firm performance. Also, a deviation from such an optimal level significantly and negatively affects firm performance. These results are consistent with the findings of Nha and Loan (2015) and Afrifa and Padachi (2016). This paper also contributes to the literature on WCM as it provides evidence of a quadratic relationship for large firms; this is important because previous researchers have mostly considered SMEs. Practically, the study will benefit firms operating within Nigeria and African countries, by extension, as the quadratic framework could be used to promote the adoption of best practices for maintaining optimal level of investment in WCM to enhance firm performance and create sustainable growth.

\section{Limitations of the Study and Suggestions for Further Research}

This paper extends the borders of WCM literature by considering the quadratic relationship between WCM and firm performance in Nigeria. However, there are a few methodological limitations which should be considered when interpreting the results. Firstly, because of resource constraints, the paper only considered the Nigerian economy out of the fifty-four (54) countries in Africa. Therefore, to generalize the results of this paper, more studies need to be done within African and other developing countries. Secondly, the paper only considered non-financial firms but a consideration of financial firms in future studies could add to the robustness of the present findings. Thirdly, as can be observed from Table 3.6, one of the control variables (firm size) of this paper was omitted because of multicollinearity when Interact was introduced for the ROA model. This contradicts the result of the variance inflation factor (VIF) and correlation analysis reported, which suggests that multicollinearity is not a threat in the study. This inconsistency may be attributed to the effect of the limited number of control variables examined in this study as indicated by the $\mathrm{R}^{2}$. As such further studies with more control variables, with or without the omitted one (firm size) in this study, is recommended. This will help to determine the sensitivity of firm size (FSz) to Interact. Moreover, a general recommendation is that more research needs to be done on the quadratic relationship between WCM and firm performance. This call is informed by the result of this paper which has demonstrated that either high or low investment in WCM has implications and poses serious risk to firms in achieving sustainable growth.

\section{References}

Adebimpe, O.U \& Ekubiat, J.U (2015). Working capital management and the performance of selected deposit money banks in Nigeria. British Journal of Economics, Management \& Trade, 7(1) 23-31.

Ademola, O. J. (2014). Working capital management and profitability of selected quoted food and beverages manufacturing firms in Nigeria. European Journal of Accounting and Auditing and Financial. Research, 2(3), 10-21.

Afrifa, G. A., \& Padachi, K. (2016). Working capital level influence on SME profitability. Journal of Small Business and Enterprise Development, 23(1), 44-63.

Afza, T., \& Nazir, M. S. (2007). Is it better to be aggressive or conservative in managing working capital? Journal of quality and technology management, 3(2), 11-21.

Baltagi, B. H (2005). Econometric analysis of panel data. (3'rd Edition). England, John Wiley \& Sons. 
Baños-Caballero, S., García-Teruel, P. J., \& Martínez-Solano, P. (2014). Working capital management, corporate performance, and financial constraints. Journal of Business Research, 67(3), 332-338.

Baños-Caballero, S., García-Teruel, P. J., \& Martínez-Solano, P. (2014). Working capital management, corporate performance, and financial constraints. Journal of Business Research, 67(3), 332-338.

Bolek, M. (2013). Working capital management, profitability and risk-analyses of companies listed on the Warsaw Stock Exchange. e-Finanse, 9(3), 1-10.

Bui, N. D., \& Nguyen, L. T. (2015). Working capital management and firm value: evidence from the Vietnamese Stock Market. Browser Download This Paper.

Capkun, V., Hameri, A. P., \& Weiss, L. A. (2009). On the relationship between inventory and financial performance in manufacturing companies. International Journal of Operations $\mathcal{E}$ Production Management, 29(8), 789-806.

Charitou, M. S., Elfani, M., \& Lois, P. (2010). The effect of working capital management on firms' profitability: Empirical evidence from an emerging market. Journal of Business $\mathcal{E}$ Economics Research (JBER), 8(12), 63-68.

Charitou, M. S., Lois, P. \& Budi Santoso, H. (2012). The effect of working capital management on firms' profitability: Empirical evidence from an emerging market. Journal of Business $\mathcal{E}$ Economics Research (JBER), 8(12).

Dehnel, G. (2014). Winsorization methods in polish business survey. Sampling methods and estimation, Statistics in Transition New Series, Winter, 15(1), 97-110.

Deloof, M. (2003). Does working capital management affect profitability of Belgian firms? Journal of business finance $\mathcal{E}$ Accounting, 30(3ロ4), 573-588.

Ebenezer, A. B., \& Asiedu, M. K. (2013). The relationship between working capital management and profitability of listed manufacturing companies in Ghana. International Journal of Business and Social Research, 3(2), 25-34.

Eljelly, A. M. (2004). Liquidity $\square$ profitability tradeoff: An empirical investigation in an emerging market. International Journal of Commerce and Management, 14(2), 48-61.

El-Maude, J. G., \& Shuaib, A. I. (2016). Empirical examination of the association of working capital management and firms' profitability of the listed food and beverages firms in Nigeria. Researchers World, 7(1), 12-22.

Filbeck, G., \& Krueger, T. M. (2005). An analysis of working capital management results across industries. American Journal of Business, 20(2), 11-20.

Hsiao, C., (2003), Analysis of Panel (Data. 2nd Edition). Cambridge: Cambridge University Press.

Iqbal, N., Ahmad, N., \& Riaz, Z. (2014). The relationship between working capital management and profitability: Evidence from Pakistan. International Letters of Social and Humanistic Sciences, (20), 14-25.

Karaduman, H. A., Akas, H. E., Zonogon, A., \& Durer, S. (2010). Effects of working capital management on profitability: the case for selected companies in the Istanbul stock exchange (2005-2008). International Journal of Economics and finance Studies, 2(2), 47-54.

Kaushik, R., Lapland, M., \& Mousasi, R. (2006). Corporate working capital management: determinants and consequences. International Journal of Managerial Finance, 3(2), 164-177.

Kline, R.B (2011) Principles and practice of structural equation modelling. (3 ${ }^{\text {rd }}$ Edition). The Guilford Press, New York London.

Lazaridis, I., \& Tryfonidis, D. (2006). Relationship between working capital management and profitability of listed companies in the Athens stock exchange. Journal of Financial Management and Analysis, 19(1), 1-12.

Lyngstadaas, H., \& Berg, T. (2016). Working capital management: evidence from Norway. International Journal of Managerial Finance, 12(3), 295-313.

Makori, D. M \& Jagongo, A. O., (2013). Working capital management and firm profitability: Empirical evidence from manufacturing and construction firms listed on Nairobi Securities Exchange, Kenya. International Journal of Accounting and Taxation, 1(1), 1-14. 
Martínez-Sola, C., García-Teruel, P. J., \& Martínez-Solano, P. (2014). Trade credit and SME profitability. Small Business Economics, 42(3), 561-577.

Mathuva, D.M. (2010). The influence of working capital management components on corporate profitability: A survey on Kenyan listed firms. Research Journal of Business Management, 4(1)1-11.

Mitchell, C (2016) Oil price fall is the main reason for tough times in Nigeria. Financial Times Retrieved from:https://www.ft.com/content/3a47381a-7371-11e6-bf48-b372cdb1043a.

Napompech, K. (2012). Effects of working capital management on the profitability of Thai listed firms. International Journal of Trade, Economics and Finance, 3(3), 227-232.

Nha, B. D., \& Loan, N. T. (2015). Working capital management and firm value: Evidence from the Vietnamese Stock Market. Browser Download This Paper.

Nnorom, N (2015, March 27) CBN policy: massive job cuts looms in manufacturing sector. Vanguard. Retrieved from: http://www.vanguardngr.com/2015/10/cbn-policy-massive-job-cuts-loomsin-manufacturing-sector/.

Nobanee, H., Abdullatif, M., \& AlHajjar, M. (2011). Cash conversion cycle and firm's performance of Japanese firms. Asian Review of Accounting, 19(2), 147-156.

Orobia, L. A., Padachi, K., \& Monoene, J. C. (2016). Why some small businesses ignore austere working capital management routines? Journal of Accounting in Emerging Economies, 6(2), 94110.

Owolabi, S. A., \& Alu, C. N. (2012). Effective working capital management and profitability: a study of selected quoted manufacturing companies in Nigeria. Economic and Finance Review, 2(6), 5567.

Pais, M. A., \& Gama, P. M. (2015). Working capital management and SMEs profitability: Portuguese evidence. International Journal of Managerial Finance, 11(3), 341-358.

Pervan, M., \& Višić, J. (2012). Influence of firm size on its business success. Croatian Operational Research Review, 3(1), 213-223.

Salawu, R. O. (2005). Industry practice and aggressive conservative working capital policies in Nigeria. Editorial Advisory Board e, 13(3), 294-304.

Salman, A. Y., Folajin, O. O., \& Oromo, A. O. (2014). Working capital management and profitability: A study of selected listed manufacturing companies in Nigerian Stock Exchange. International Journal of Academic Research in Business and Social Sciences, 4(8), 287-295.

Samiloglun, F. \& Demirgunes, K. (2008). The effect of working capital on firm performance: Evidence from Turkey. The Journal of Applied Economics and Finance. 2(1), 44-50.

Sanusi, L. S. (2010). Growth prospects for the Nigerian economy. Eighth Convocation lecture of the Igbinedion University, Okada, Edo State, Nigeria. Retrieved from: https://scholar.google.com/scholar?q=Sanusi+Lamido+Sanusi\%3A+Growth+prospects+for+t he+Nigerian+economy+Convocation+lecture+by+Mr+Sanusi+Lamido+Sanusi $\% 2 \mathrm{C}+$ Governor + of +the+Central+Bank+of+Nigeria $\% 2 C+$ at+the+Igbinedion\&btnG $=\& h l=$ en\&as_sdt $=0 \% 2 \mathrm{C} 5$.

Sayne, A \& Hruby, A. (2016, January) Nigeria's oil revenue crunch: falling price and increased competition strain the economy and stability. Atlantic Council. Retrieved from: https://www.files.ethz.ch/isn/195769/Nigeria_s_Oil_Revenue_Crunch_web.pdf.

Sharma, A. K., \& Kumar, S. (2011). Effect of working capital management on firm profitability empirical evidence from India. Global Business Review, 12(1), 159-173.

Sharma, M. P. G., \& Kaur, M. R. P. (2016). Working capital management and its impact on profitability: A case study of Bharti Airtel Telecom company. Imperial Journal of Interdisciplinary Research, 2(3), 265-271.

Shin, H. H., \& Soenen, L. (1998). Efficiency of working capital management and corporate profitability. Financial practice and education, 8, 37-45.

Tauringana, V., \& Adjapong Afrifa, G. (2013). The relative importance of working capital management and its components to SMEs' profitability. Journal of Small Business and Enterprise Development, 20(3), 453-469. 
Uwuigbe, O., Uwalomwa, U., \& Egbide, B. C. (2011). Cash management and corporate profitability: a study of selected listed manufacturing firms in Nigeria. Acta Universitatis Danubius. CEconomica, 8(1), 49-59.

Wasiuzzaman, S. (2015). Working capital and firm value in an emerging market. International Journal of Managerial Finance, 11(1), 60-79.

Yazdanfar, D., \& Öhman, P. (2014). The impact of cash conversion cycle on firm profitability: An empirical study based on Swedish data. International Journal of Managerial Finance, 10(4), 442452. 